forçassent à avouer son emprunt; mais la connaissance de son caractère donne à l'acte qu'on lui reproche une probabilité voisine de la certitude. Une lettre d'Huyghens à L'Hospital est sur ce point fort instructive.

"' 'M. Leibnitz,' dit Huyghens, 'est assurément très babile, mais il a avec cela une envie immodérée de paroitre, comme cela se voit, lorsqu'il parle de son Analyse des infinis . . . , des lois harmoniques des mouvemens planétaires, où il a suivi l'invention de M. Newton, mais en y meslant ses pensées qui la gastent .. Encore suis-je fort en doute, pour des raisons que je pourrois alléguer, s'il n'a pas tiré sa construction (de la chaînette) de celle de M. Bernoulli.

“Dans la préface de son 'Calcul différentiel,' Euler n'attribue à Leibnitz que la réduction des principes de Newton en systême. Lagrange, qui cherche chez Fermat l'origine du Calcul differentiel, ne manque pas, dans ses 'Leçons sur le Calcul des Fonctions,' de signaler les concordances de l'écrit de Leibnitz de 1684, avec la théorie antérieure de Fermat. Gauss pensait, comme on le voit dans l'écrit de Sartorius de Waltershausen, que Leibnitz, même de loin, ne doit pas être comparé à Newton."

It is satisfactory to quote Herr Diihring through his reviewer, because the introductory sentence of the extract makes evident to those not already aware of M. Bertrand's historical leanings that it is on Dr. Ingleby's side the eminent French mathematician would give his voice.

High School of Glasgow, March I7

\section{Blue Flame from Common Salt}

SOME time ago the question was raised in NATURE (vol. xiii. p. 287 ) concerning the origin of the blue flame produced when common salt is thrown into a hot fire.

Among the suggestions that were advanced, no one offered the only explanation that is at all feasible, viz., that it is due simply to hydrochloric acid.

The blue flame is not produced by sodium chloride only, but by other chlorides as well. Those I have tried are $\mathrm{BaCl}_{2}$, $\mathrm{SrCl}_{2}, \mathrm{KCl}, \mathrm{AmCl}, \mathrm{Hg}_{2} \mathrm{Cl}_{2}$, and $\mathrm{HCl}$, the last both in solution and as gas.

It would be waste of time and space to enumerate all the experiments I have made on this subject; many of them were for the purpose of proving that neither carbon nor sulphur had any share in the reaction.
One of my methods of obtaining the flame was to burn pure hydrogen from a glass jet, and allow a mingled stream of $\mathrm{HCl}$ and $\mathrm{NH}_{3}$ from two other jets to pass into it. The best source, however, is calomel, heated on wire gauze by a Bunsen burner; the next best, AmCI.

The spectrum of the "chloride" flame is characterised by a series of double bands in the green, blue, and violet, the least refrangible of each pair being the broadest. The four pairs in the violet are especially prominent. There are two red bands or lines, and one orange. The least refrangible red line occupies the place of the hydrogen line C.

A spark between carbon points in a bottle of $\mathrm{HCl}$ gas yields a spectrum similar in appearance to that obtained from a chloride, but 1 was unable to see any violet bands, only a faint continuous spectrum.

I was able to ascertain that the red lines coincided exactly,

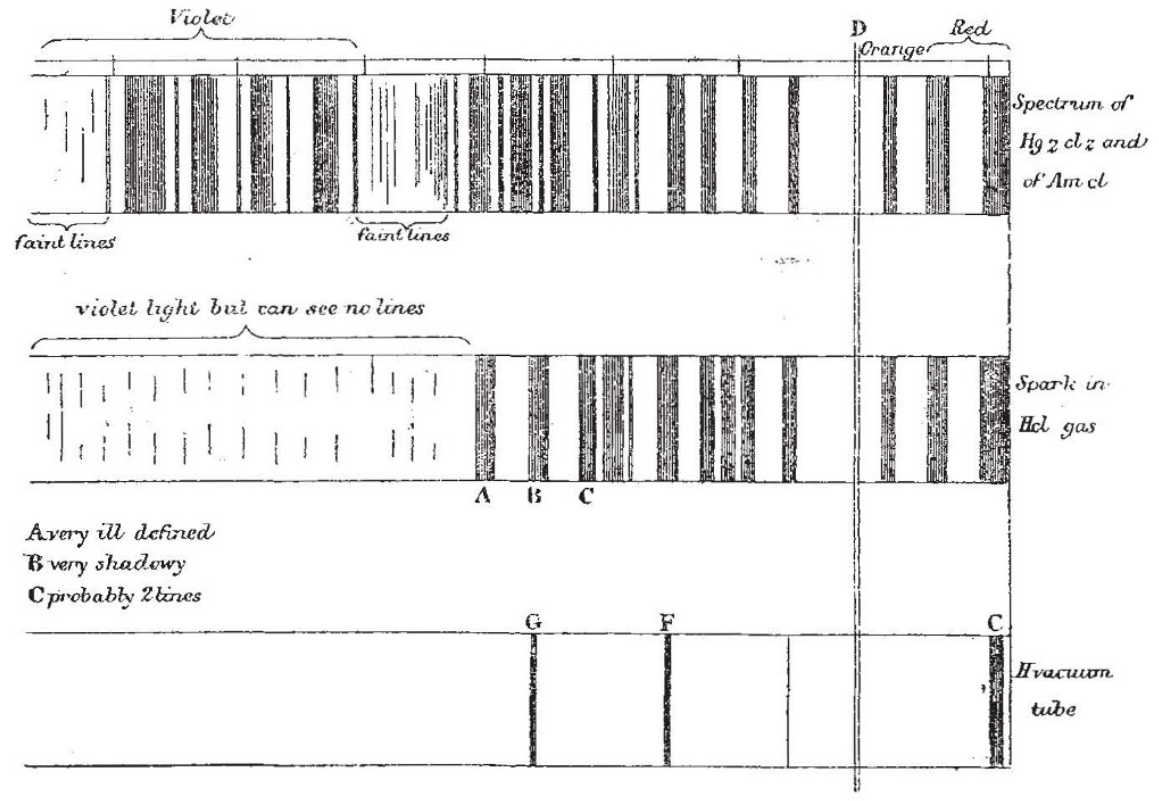

tut I cannot affirm with the same positiveness that all the green lines and bands coincide. Some undoubtedly do, but the spectrum of the $\mathrm{HCl}$ was so faint, and the spectrum of the chloride so transient, that measurements were very difficult, and I do not pretend to any high degree of accuracy in my delineations of the lines, besides the different conditions under which the two were compared might account for considerable variations. For the $\mathrm{HCl} I$ used a coil (capable of giving a $2^{\prime \prime}$ spark) with Leyden jar, worked by six Smees. The carbon points were $\frac{1}{3}$ inch apart. The spark was tried both focussed and unfocussed on the slit of a 2-prism spectroscope. When comparing the two spectra side by side it was difficult in some cases to be sure of coincidence, because the flame from the $\mathrm{Hg}_{2} \mathrm{Cl}_{3}$ would flash out brilliantly for a moment and quite overpower the more feeble lines of the $\mathrm{HCl}$; it would then disappear entirely, and more chloride would have to be placed on the gauze.
$I$ have no doubt in my own mind that $\mathrm{HCl}$ is the cause of the blue flame. I have proved that $\mathrm{CI}$ is a necessary constituent, and I have not been able to get it in the absence of hydrogen (the spectrum of pure $\mathrm{Cl}$ is very different), and besides the red $\mathrm{H}$-line is present in both cases, and probably the other two as well. I do not think that the presence of aqueous vapour is sufficient to account for the red line.

I subjoin the spectra as I mapped them, but it must be borne in mind that $I$ do not vouch that they are free from error. I intend to photograph them when I have sufficient leisure, and I hope the results will be more definite. I may be able to find violet lines in the spectrum of $\mathrm{HCl}$.

Temple Obsexvatory, Rugby,

A. PERCy SMrTH March 15 